\section{Reflexão Bioética: a evolução biotecnológica sob os prismas do início da vida e da justiça}

\section{Ribeiro, Rodrigo Alves}

Estudante de Direito. Universidade de Uberaba - UNIUBE. e-mail: equipeinstalacoes@gmail.com

PALAVRAS-CHAVE: Bioética, Biotecnologia, Início da Vida, Justiça

Introdução: A Bioética e a Biotecnologia se relacionam desde a morfologia das palavras à aplicação prática paulatinamente. Cumpre identificar o vínculo existente entre os fundamentos da Bioética e a última. Nesse prisma, nota-se o princípio da justiça. Dada a evolução tecnológica, urge refletir sobre onde estamos e para qual lugar vamos, com indispensável reflexão ética sobre o justo, confrontando a evolução tecnológica à obrigação de aplicar parcimônia na discussão sobre o início da vida. A metodologia utilizada contempla o levantamento e revisão bibliográfica, bem como estudo histórico sobre o assunto. Resultados: Desde o descobrimento do arcabouço do DNA em meados do século $\mathrm{XX}$, a biotecnologia ganhou notória projeção. Na época, a façanha inovadora abria portas para uma nova era. Os avanços tecnológicos na seara da vida e saúde transitariam por lugares jamais explorados. "Toda realidade onde existe a participação da vida haverá desafios. Os desafios devem ser encarados como possibilidade real de superação" (SANTOS, 2017, P. 72). A grande evolução biotecnológica, em que pesem os benefícios galgados com a engenharia genética, transplantes, procedimentos embrionários, reprodução assistida, células tronco e pesquisas com seres humanos, é encarada como um grande desafio; soma-se a isso, a discussão sobre o início da vida e a justiça. No que tange à vida humana friza-se a diversidade de conceitos e teses sobre quando se dá o início da vida, do ser humano e mesmo da pessoa humana. São diversos os entendimentos religiosos acerca do tema, como o católico, defendendo que o processo se dá no momento da fecundação, encontro do espermatozoide com o óvulo. No âmbito científico vislumbramos a visão concepcionista; a da atividade pulmonar, possibilidade vital fora do útero materno; da atividade neurológica, utilização do marco final da vida para o início dessa; da crença da vida viável, aderência do embrião à parede intrauterina, nidação. Em detrimento aos entendimentos supracitados, "os especialistas distinguem vida humana e pessoa humana. Zigoto é vida humana, mas é pessoa humana, sujeita de direitos? A reflexão necessita do concurso de várias ciências" (BARCHIFONTAINE, 2004, P.113). Retomando o viés da Bioética Principialista, cumpre analisar os avanços técnico-científicos à luz da justiça. O estudo e técnicas já utilizadas pela Biociência precisam estar regados de responsabilidade. Nessa linha o filósofo alemão Hans Jonas em O Princípio da Responsabilidade, alerta que o hoje influencia diretamente na vida das gerações futuras. Assim, exige-se cautela para não debruçar no utilitarismo. Evolução a todo custo. Afronta a princípios axiológicos e legais para cambiamentos científicos. "Não é possível resolver a questão legal sem considerar a questão moral e religiosa implícita" (SANDEL, 2017, P. 314). Nesse pensamento, "justiça não é apenas a forma certa de distribuir as coisas. Ela também diz respeito à forma certa de avaliar as coisas" (SANDEL, 2017, P.323). Conclusão: O aprendizado empírico, nos leva a evitar erros do passado. A evolução da Biociência precisa observar o diálogo, a satisfação da ética, a justiça. Ė necessário evoluir, todavia observando com justiça os parâmetros referentes ao início da vida.

AGRADECIMENTOS. Agradeço a minha esposa Valesca e ao meu filho Lucas, que me compreendem e apoiam na jornada em busca do conhecimento. Ao núcleo de pesquisa em Bioética e Biodireito - $\mathrm{Nebio}^{2}$ - da Universidade de Uberaba. Ao mestre Sávio Gonçalves dos Santos por acreditar em mim e à parceira de iniciação científica Elisa Kiosz da Silveira.

\section{REFERÊNCIAS}

[1] BARCHIFONTAINE, Christian de Paul. Bioética e início da vida: Alguns desafios. São Paulo: Idéias e Letras, 2004. p.113.

[2] SANDEL, Michael J. Justiça - o que é fazer a coisa certa. $24^{\mathrm{a}}$ Edição. Rio de Janeiro: Civilização Brasileira, 2017, p.314-323.

[3] SANTOS, Sávio Gonçalves. Método Gentificar. $1^{\mathrm{a}}$ Edição. Rio de Janeiro: Multifoco,2017, p.72. 